Journal of Engineering and Applied Sciences 15 (1): 141-152, 2020

ISSN: 1816-949X

(C) Medwell Journals, 2020

\title{
Sustainability of Slum-Based Settlement Management Community Socio-Economic Empowerment (Study on Slum Settlements in Panakkukang District, Makassar City)
}

\author{
Batara Surya, Haeruddin Saleh and Herminawaty Abubakr \\ Department of Urban and Regional Planning Bosowa University, Makassar, Indonesia
}

\begin{abstract}
Urban development studies are oriented towards the development of business centers, relating to poverty, marginality, community powerlessness and the emergence of urban slums. This study, therefore, aims to examine and analyze shanty town management, based on socio-economic empowerment using qualitative and quantitative approach. Furthermore, data was obtained through observation, surveys and documentation and the results indicated that business-oriented development has a direct impact on the expansion of informal activities and slums. However, important findings showed development policies emphasizes capital owners and ignores marginal and poor urban communities, therefore, triggering the emergence of favelas in protected areas which fosters the progress of the informal sector.
\end{abstract}

Key words: Slums, dualistic economy, socio empowerment, socio-economy, sustainable development, informal

\section{INTRODUCTION}

Economic globalization in the development of Makassar city focuses on fiscal growth, business centers and the hierarchy of urban service complexes where global metropolises are relatively central nodes in worldwide grading (Timberlake et al., 2014). However, linkages among metropolises are more complicated and diversified in this era. Therefore, regional economic collaborative development has become more important than before (Chen and Liu, 2019). Furthermore, commercial growth-oriented expansion in the urban areas of Makassar city leads to profitable agglomeration and the integration of urban and rural system activities serves as a progress unit for the Mamminasata Metropolitan area which generally, plays a dominant role in urban-rural integration (He et al., 2019). However, urbanization in Panakkukang District, due to fiscal polarization in the center of the metropolis, resulted in inequality of land tenure and income within the community at each developmental stage. Moreover, this worsens income inequality and the relationship is therefore, non-linear and phase dependent (Sulemana et al., 2019).

The elevation in the population of Panakkukang Sub-District as the business center of Makassar city resulted in the emergence of slums within protected areas which are a defining part of major evolving countries of the urban scape. Furthermore, their supply of energy, basic infrastructure, among others a principal challenge of modern civilizations (Friesen et al., 2018). Thus, their characteristics in the area include high population density, poor sanitation, decreased quality of the environment, urban crime, irregularities in the layout of buildings, uninhabitable buildings and poverty. Furthermore, the number of dwellings present, characterized by the lack of sanitation and public services, inadequate construction conditions and irregular land tenure, also grew at very high rates (Pedro and Queiroz, 2019).

The development further accelerated changes in spatial use and dimensional integration, leading to financial growth, positively associated with dualistic economies, formal settlements and slums, based on the development of hierarchies in the region. Furthermore, state involvement also supports urban growth and produces distortions, as the dominance of the informal sector in public areas are consequences of the improvement of business activities, based on industrialization and modernization (Wang, 2014). However, these processes have resulted in income inequalities, positively associated with the advancement of slums and the formation of cities is a direct result of fiscal growth, particularly the rapid industrialization in developing countries (Ding et al., 2012).

The existence of slums developed alongside the pace of the informal economy in area resulted in traffic congestion, reduced environmental quality and a gap in residential ownership between groups of people, based on status and wealth. Hence, they require comprehensive and integrated management, through control policies. Therefore, governments are tasked with providing adequate fresh lands, to ensure economic development and industrialization, accommodate immigrants from rural areas and improve urban housing conditions (Han and Lai, 2012). 
The Panakkukang Sub-District area which is the object of research in this study is a business center developed to support the economic growth of Makassar city-affecting spatial patterns and urban forms. However, the advancement pace requires supporting urban and community facilities to coincide with the form's impact (Lang et al., 2019). Hence, the rapid acceleration is positively associated with municipal problems, therefore, requiring the formulation of policies that focus on environmental, economic and social sustainability which plays a key role in enhancing their resilience and sustainability (Sharifi, 2019).

The development of municipal activities in this area is characterized by the existence of shopping centers, elite settlements, entertainment facilities, hotels and restaurants which affects the transportation system. Furthermore, rapid growth, coupled with a legacy of under investment and laissez-faire governance has resulted in acute traffic congestion (Fox et al., 2019). The advancement of the business center agrees with the growth of shanty towns along the banks of the Tallo River and urban informal economic activities of which most are located along the main roads. However, an important element in reducing poverty, here, involves a policy framework that guarantees inclusive municipal development, provision of livelihood opportunities and accumulation of assets for the poor (Olajide et al., 2018).

The coexistence of the dualistic economy system as well as differences in the modes of production (capitalism and pre-capitalism) in studied the area, indicates the inequality in land tenure and variance in relations amongst fiscal agents. The capitalist mode runs through technological and capital support while the pre-capitalism mode operates with the sustenance of simple tech skills (Surya and Saleh, 2018a). However, these alterations require institutional backings to manage development and socio-economic empowerment of the poor, through cooperation between government and private institutions. Furthermore, economic coalitions are expected to actualize between local governments and developers while political coalitions are to exist between the central and local governments (Zhang, 2014).

With reference to the thoughts previously described, the focus of this study, therefore was to examine and analyze the existence of slums and the urban informal sector as well as the management, based on sustainable socio-economic empowerment of Panakkukang Sub-District, Makassar city. However, the findings have an important contribution in the implementation of its development policy as the core city in the Mamminasata Metropolitan urban system, oriented towards economic growth and its impact on the income gap between community groups. Furthermore, development policies oriented to poor and marginal socio-empowerment is needed to solve problems of management and informal economic activities, for big cities and metropolis in developing countries.

Approach to case study and research methodology: Accelerating of the development of Makassar city was marked by the advancement of a business center, oriented towards economic growth. Panakkukang Sub-District tends to possess a dualistic economy system, characterized by formal and informal fiscal activities. Conversely, there are formal settlements built by developers and informal settlements independently constructed by communities, based on their economic abilities. Unfortunately, the advancement of unofficial suburbs, leads to the existence of slums, encompassing all of the complex problems including inhabitation by urban poor groups with improper housing facilities, poor sanitation, increased probability of flood and fire, environmental degradation and inadequate quality of infrastructure. Furthermore, the case study used in this research was aimed to study, analyze and describe the phenomenon of slums and informal economic activities, located in the business center of the area. However, the socio-economic empowerment was expected to be a solution in its management which agrees with the focus of naturalistic, holistic and phenomenological studies (Denzin and Lincoln, 2009).

A case study was used to investigate and analyze the existence of slums and informal economic activities in the business center of the Sub-District, chosen by considering the pattern of development of shanty towns, specifically inhabited by urban poor groups, the prominent consistency and sequences in the context of cases, the existence of complex circumstances and the nature of instances were used to identify the background of a particular event which occur in the business center of Panakkukang Sub-District, Makassar city. Furthermore, the research was conducted from June 2017-January 2018 (Fig. 1) using a qualitative-quantitative combined approach. However, the philosophical reasons for this method were the logic of triangulation where the results of qualitative research are checked quantitatively and vice versa, a collection of both provides a general picture, enumerative investigation is used on structural features of social life while qualitative is used on the assessment of value for the subject as a starting point, a quantitative approach analyzes the relationships among the changes, while qualitative tactics help harmonize the factors underlying the relationship, quantitative methods are used to reveal structural large-scale social life characteristics while the latter is applied in small-scale behaviors, intended to develop the research hypothesis. Thus, the combination is used to uncover both levels and to further obtain data from two dissimilar realities. 


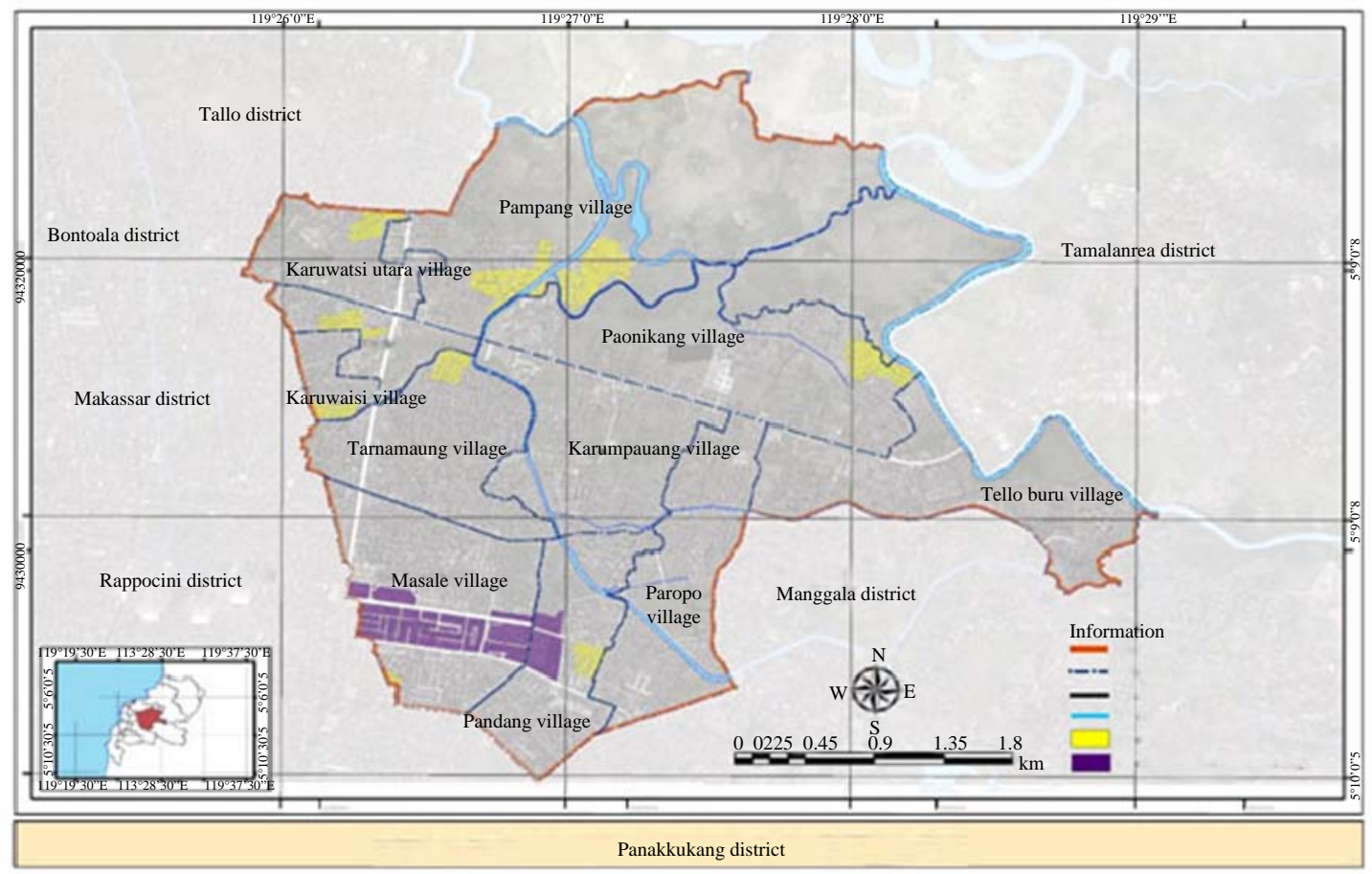

Fig. 1: Panakkukang sub-district area of Makassar city as the research object

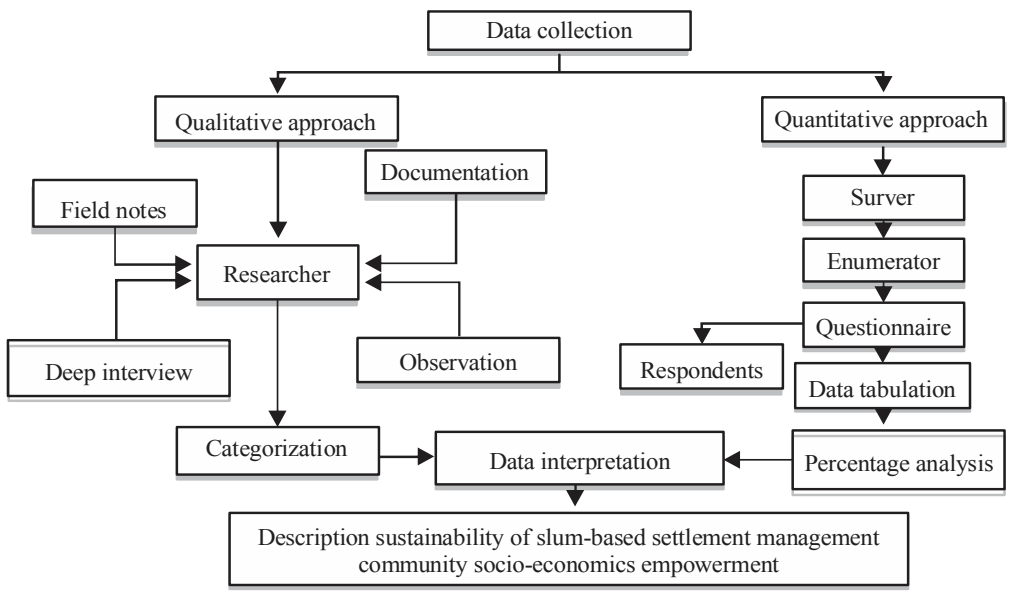

Fig. 2: Combination of qualitative and quantitative approaches

Research sites: This study was conducted in Panakkukang Sub-District, Makassar city which was determined based on the existence of formal and informal fiscal activities, dualistic economy systems, proper and improper residential areas with economic disparities between community groups and slums predominantly inhabited by poor groups and marginal.

Method of collecting data: Data collection in this study include observation which was used to spot the formal/informal economic system, the pattern of development of slums and their effects on the condition of the ecosystem of the environment, the survey which was applied to understand and describe the social and economic behavior of the community using stratified random sampling, documentation used to describe the spatial pattern of slums in Panakkukang Sub-District, Makassar city. The combination of qualitative-quantitative approaches is shown in Fig. 2. 


\section{MATERIALS AND METHODS}

Data analysis method: The analytical methods applied in this study include, quantitative descriptive statistics, for analyzing survey results data, study documentation with content analysis method, to interpret observational data and focus group discussions obtained, hypothesis from the results of qualitative studies were tested statistically using the path analysis method to determine its effect on the variables studied. However, the instrument used was the interval scale, encompassing the parametric statistics. Furthermore, data analyses were carried out as follow: analyses of qualitative and quantitative information, conducted using descriptive statistical analysis, both data were interpreted with triangulation or between methods and the processes were handled during data collection phase and afterward. Furthermore, it is aimed to obtain the similarity of respondent's answers regarding real conditions in the field. Hence, during the interview, the responses were analyzed to a certain extent, in order to obtain credible data-through data reduction, information display and conclusion drawing/verifying.

\section{RESULTS AND DISCUSSION}

Administratively, Panakkukang Sub-District covers 11 villages with 147,783 residents. The development of this region was marked by the accumulation of various urban activities, of which most are located on the main road section, marked by the City Mall and the existence of shopping centers.

The increase in population (Fig. 3) caused by growth and urban expansion impacts considerably on the intensity of spatial use and the conversion of buildings towards the development of commercial functions. However, the dimensional attributes in the Panakkukang Sub-District business center are characterized by the existence of economic activities including shopping centers, hotels, services, banking, restaurants, cafes and others causing major changes in land use and growth patterns in the metropolitan area. Furthermore, economic evolution and urban agglomerations are positively associated with the development of slums indicated by a decline in the quality of the environment. However, ecological degradation gradually exhibits a restrictive effect on socio-economic sub-system, hence, restricting the improvement of the coordinated development (Yang and $\mathrm{Hu}, 2019)$. The facts acquired in the field indicated that the rapid advancement leads to the dominance of informal municipal activities on the main road sections, causing traffic congestion and misuse of roadsides as parking lots. Furthermore, these activities do not only contribute to the fiscal growth of most countries but they also significantly affect the built environment (Farinmadea et al., 2018). Therefore, the conversion of residential buildings into commercial, led to the coexistence of urban formal and informal economies. However, these further indicated the evolution in the function of buildings along the main road into hotels and offices. Hence, the coexistence and disparity in production modes display the imbalance of land tenure and the production economy, dominated by capitalists (Surya et al., 2018b).

Characteristics of formal settlements and slum settlements of Panakkukang district: The development of the business center in Panakkukang Sub-District is subsequently followed by the expansion of slums as the general settlements are directly related to the existence of functions of economic and other urban activities. However, several factors contributing to this problem include the socio-economic, environmental, unequal

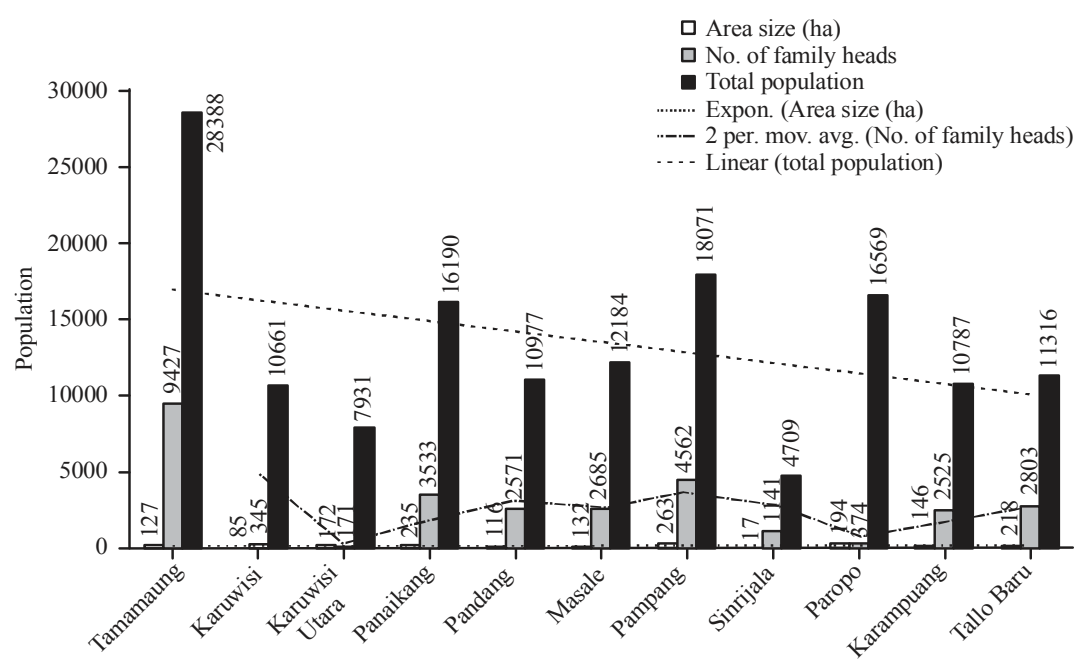

Fig. 3: Number and population density of Panakkukang Sub-District of Makassar city in 2018 

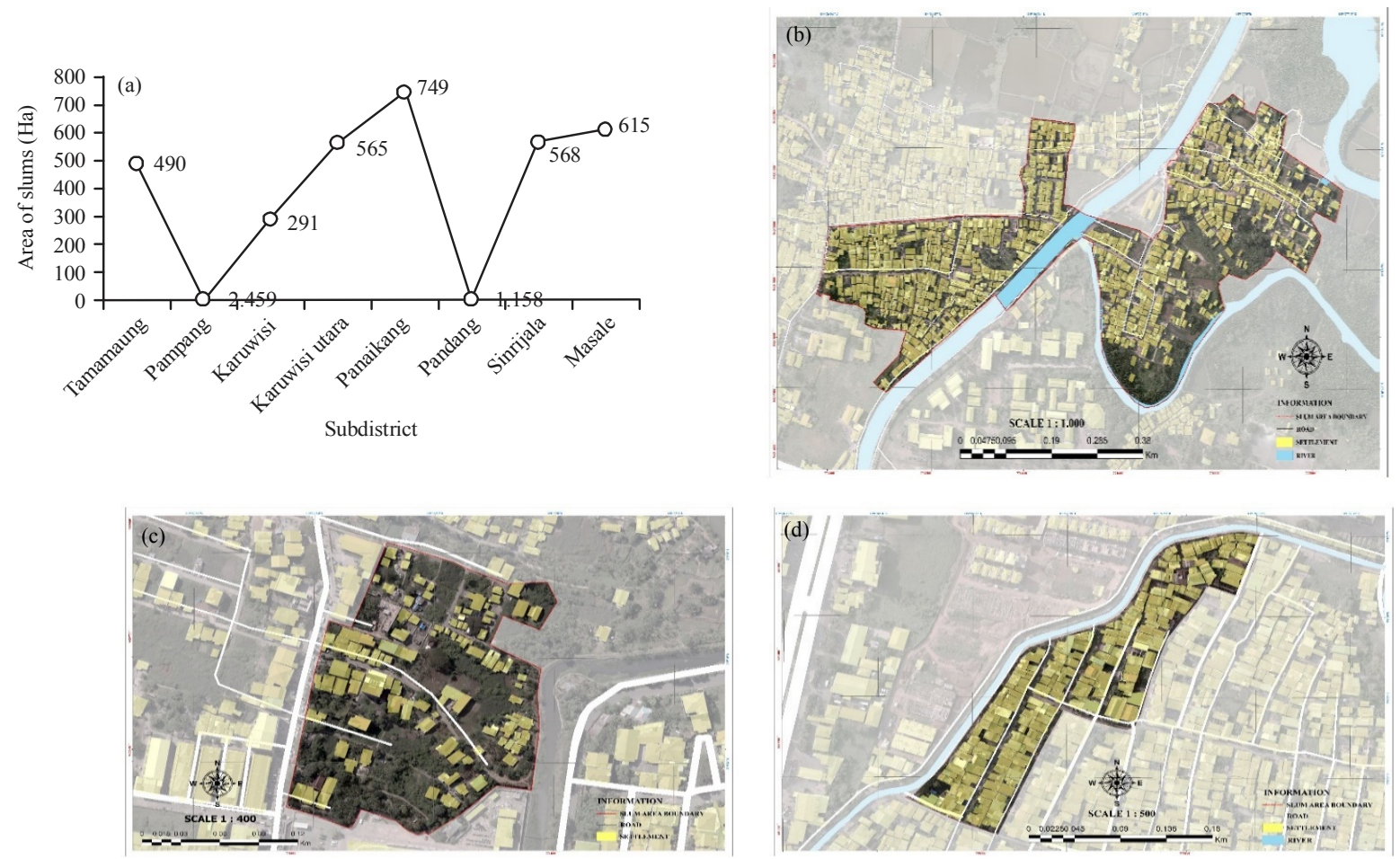

Fig. 4(a-d): Example spatial patterns and morphology of slums in Panakkukang Sub-District, Makassar city (a) Area of slum settlements in Panakkukang District, (b) Slum settlement in Pampang village (Tallo river area), (c) Slum settlement of pandang village (business center area Panakkukang) and (d) Sinrijala slum settlement (education center and Tallo river area)

distribution of urban resources and the wide gap between the rich and the poor (Soyinka and Siu, 2018). Therefore, the obtained data indicated that community poverty was positively associated with the ownership of inhabitable settlements and subsequently, urban, economic and social spatial segregations.

Figure 4 shows the distribution of slums in Panakkukang Sub-District indicating the presence of the largest area in Pampang village with 2,459 ha and the smallest was in Kuruwisi village (291 ha). Furthermore, the obtained data showed that these areas were inhabited by urban poor people with several characteristics such as: poor sanitation, fire hazard, minimum housing conditions, urban crime, environmental degradation and scarcity of facilities and infrastructure. However, the number of dwellings was characterized by the lack of sanitation and public services, inadequate construction conditions and irregular land tenure, at very high rates (Pedro and Queiroz, 2019). The statistics showed 2,275 poor individuals lived in slums around the business center within the Sub-District and the developing business center positively correlates with the existence of formal settlements, built by developers, consisting of medium to very luxurious buildings. Furthermore, differences in settlements are influenced by income, therefore triggering urban spatial segregation (Surya, et al., 2018c) and the data obtained showed that this pattern and typology of settlements, possess a fundamental difference and subsequently, a very sharp income gap between populations, affected by status, stratification and economic class. Hence, the informal settlement is a policy framework that guarantees inclusive urban advancement, provision of livelihood opportunities and accumulation of assets, for the urban poor inhabitants (Olajide et al., 2018).

Interpretation submitted in Fig. 5 include: formal modern architecture-style settlements in Panakkukang Sub-District, mostly inhabited by capitalists and businessmen in the fields of hospitality, restaurants and other commercial enterprises, slums occupied by groups of urban poor people, working as street vendors, food stalls, fruit sellers and others. However, both residential typologies develop simultaneously and further exhibit segregation, based on income and differential grouping of people, based on profession and social status. Furthermore, inequality in access to ecosystem services is inextricably linked with environmental justice within socially heterogeneous urban settings (Yi et al., 2019) and the data obtained showed that the existence of slums was part of the survival techniques practiced by the poor, to survive in the city illegally, hence, arising the need for future cities, because of the rapid growth in population which causes a decline in the standard of living (Saaty and Sagir, 2015; Surya, 2015a). 

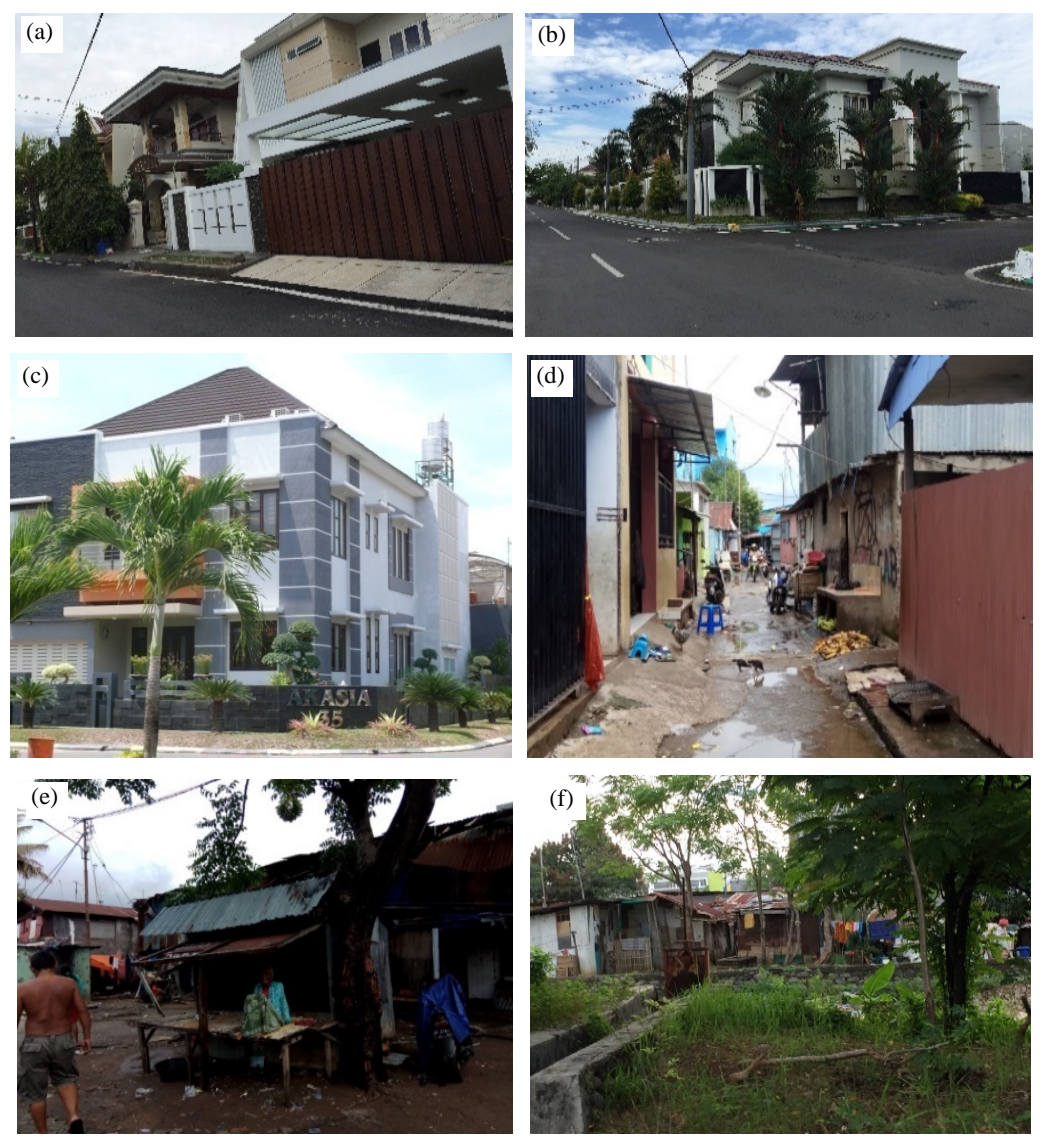

Fig. 5(a-f): Formal and informal settlements in Panakkukang Sub-District, Msakassar city

The existence of slums in Panakkukang Sub-District, Makassar city is influenced by several factors including limitations and inability to respond to the modernization of urban settlements, limited public access to municipal space reproduction, Inability to react to changes in environmental stimulus and limited capacity and expertise to obtain a decent job. Furthermore, these also affect the process of materializing spatial zoning in the region. However, coherent crisis zones were formed due to the emerging high-degree and permanent unemployment, ceasing of work places, impoverishment and massive migration of those in better social situations (Balogh et al., 2018) (Fig. 6).

The results of the analysis showed that significance values of the three variables studied were $\mathrm{X} 1=-0.164$, $\mathrm{X} 2=0.058$ and $\mathrm{X} 3=-0.044$ and all were $>0.05$, showing their indirect effect on the existence of slums. However, this means that the area needs infrastructure management, environmental quality improvement and fulfillment of facilities and infrastructure as a unified urban system. Furthermore, government local municipalities are crucial in the identification of mechanisms to align local land use plans and therefore, permitting with the goals of building subsidized units in a more desirable location (Acolin et al., 2019). Moreover, the value of $\mathrm{R}^{2}$ or $\mathrm{R}$ Square of 0.038 indicated that the contribution of the three variables (X1, X2 and X3) to $\mathrm{Y}$ was $3.80 \%$. Hence, concluding that the existence of $96.20 \%$ slums in the Panakkukang Sub-District business center was influenced by other factors.

The analysis, therefore, showed that the success of managing slums in the studied area does not only requires infrastructure management, an improvement on environmental quality and organization of urban activity but also the efforts in the sustainability of socio-economy empowerment. Hence, this obliges comprehensive and integrated planning programs and mechanisms that cover physical, economic and socio-cultural aspects, in order to suppress the growth of slums. Furthermore, this also means that socio-economic empowerment may become an opportunity for marginal and urban poor communities to have a better place to live. However, housing policies which apply the principle of justice is also a solution for dealing with slums, benefiting the wider population (Maalsen, 2019) (Table 1). 
J. Eng. Applied Sci., 15 (1): 141-152, 2020

Table 1: Model summary

\begin{tabular}{|c|c|c|c|c|c|}
\hline \multirow{2}{*}{$\begin{array}{l}\text { Coefficients } / \\
\text { Model }\end{array}$} & \multicolumn{2}{|c|}{ Unstandardized coefficient } & \multirow{2}{*}{$\begin{array}{c}\text { Standardized } \\
\text { coefficients } \\
\text { Beta }\end{array}$} & \multirow[b]{2}{*}{$\mathrm{t}$-values } & \multirow[b]{2}{*}{ Sig. } \\
\hline & $\mathrm{B}$ & SE & & & \\
\hline 1. Constant & 48.885 & 11.545 & & 4.232 & 0.000 \\
\hline Infrastructure agreement (X1) & -0.141 & 0.140 & -0.164 & -1.008 & 0.319 \\
\hline Environmental quality (X2) & 0.047 & 0.126 & 0.058 & 0.371 & 0.713 \\
\hline Urban activity pattern (X3) & -0.055 & 0.201 & -0.044 & -0.271 & 0.788 \\
\hline
\end{tabular}

Model: 1, R; 0.196a, R²: 0.038, Adjusted R²: -0.034, SE of the estimate: 6.234 , Sig. F change: 0.663 , Dependent variable: Slum settlement

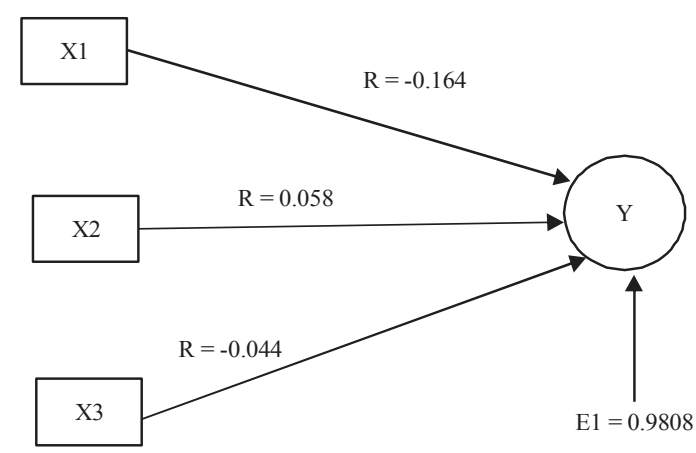

Fig. 6: The effect of existence of slums on spatial patterns in Panakkukang Sub-District, Makassar city

Dynamics of formal and in-formal economic activities: The development of the business centers in the studied region shows that capitalism-oriented growth has a direct impact on the coexistence of modes of production and also the inequality of land reproduction and tenure. Surya et al. (2018c), largely determined by capital ownership. The limited access to the community and life necessities further increase the development of informal economic activities dominated by poor individuals. However, marginality is a situation where a person or a group is at the sideline in certain social, economic or cultural characteristics, due to causal complexes which excludes such units or individuals from the rest of population (Zahra et al., 2018). Furthermore, the limitation of employment contributes positively to the differences in people's abilities during the process of adaptation to fluctuations in the environmental stimulus.

Interpretations obtained in Fig. 7 are as follows: the development of formal economic activities in the business center reinforces the influence of capitalism on urban land control within Panakkukang Sub-District, the control of reproduction of space by capitalists, triggers disparity among community groups, the intensity of changes in spatial use affects transportation movement systems in the studied region. Hence, these three basic principles influence the development of the economic activity system, in line with elevating productivity towards a dualistic fiscal structure. Furthermore, effective interactions in order to achieve advancements and enhanced quality of life of the population are attained, through an increase in the labor of the employed, introduction of new technologies and other components of growth and also by adjusting higher-quality state/in-state institutions (Menshikov and Volkova, 2018). However, limited access and differences in economic interests lead to the development of formal economic undertakings that lead to the existence and improvement of welfare while the informal actions can be observed in the following picture.

Interpretations submitted from Fig. 8 include: the development of informal activities shows the existence of urban poor people responding to environmental stimulus, through economic development, oriented to meeting needs and welfare, creating patron-client relationships, profit managed on the sharing basis and symbiotic mutual relationships between buyers and sellers. Furthermore, these four basic principles show that unofficial economic development is based on mutual trust between buyers and sellers (Surya, 2015b) and the practice along the main road sections coexists directly, therefore, influenced by fiscal behaviors created by the business being developed. Hence, this indicates that the informal financial system keeps their business closer to consumers. Therefore their existence is formed from the adaptation of urban poor groups to changes in environmental stimulus and also, the streets are the media used to carry out these activities and further create social relations. However, in a society, cities are the centers of human interactions, creativity, knowledge, diversity, culture, commerce and economic creativity (Kashkouli et al., 2018). The results of the analysis on the direct influence of the existence of the informal economy against the spatial system of the Panakkukang Sub-District area of Makassar city are as follows.

The results showed that the value of the three variables, namely $\mathrm{X} 1=-0.175, \mathrm{X} 2=0.032$ and $\mathrm{X} 3=0.204$ were higher than 0.05 and they all affect informal economic activities which ensue in the main road sections and in public spaces around the business center of the Panakkukang Sub-District. Furthermore, this implies the increase in the rate of these activities directly impact on the city transportation system, the socio-economy relationship between sellers and buyers and the fiscal pattern of the commercial focal points. However, these practices require structuring, representative room access and legality, through the Makassar city government policy. Hence, the consumer-based allocation assigns environmental impacts, associated with the provision of products and services to the final user/consumer, in the city where its utilization takes place (Alberti et al., 2019). Furthermore, 
Table 2: Model summary

\begin{tabular}{|c|c|c|c|c|c|}
\hline \multirow[b]{2}{*}{$\begin{array}{l}\text { Cofficient/ } \\
\text { Model }\end{array}$} & \multicolumn{2}{|c|}{ Unstandardized coefficient } & \multirow{2}{*}{$\begin{array}{c}\text { Standardized } \\
\text { coefficients } \\
\text { Beta } \\
\end{array}$} & \multirow[b]{2}{*}{ t-values } & \multirow[b]{2}{*}{ Sig. } \\
\hline & B & $\mathrm{SE}$ & & & \\
\hline 1. Constant & 37.913 & 11.227 & & 3.377 & 0.002 \\
\hline Transportation system (X1) & -0.167 & 0.154 & -0.175 & -1.088 & 0.287 \\
\hline Socio-ekonomic relation (X2) & 0.033 & 0.159 & 0.032 & 0.204 & 0.839 \\
\hline Pattern of economic activity (X3) & -0.223 & 0.176 & -0.204 & 1.263 & 0.214 \\
\hline
\end{tabular}
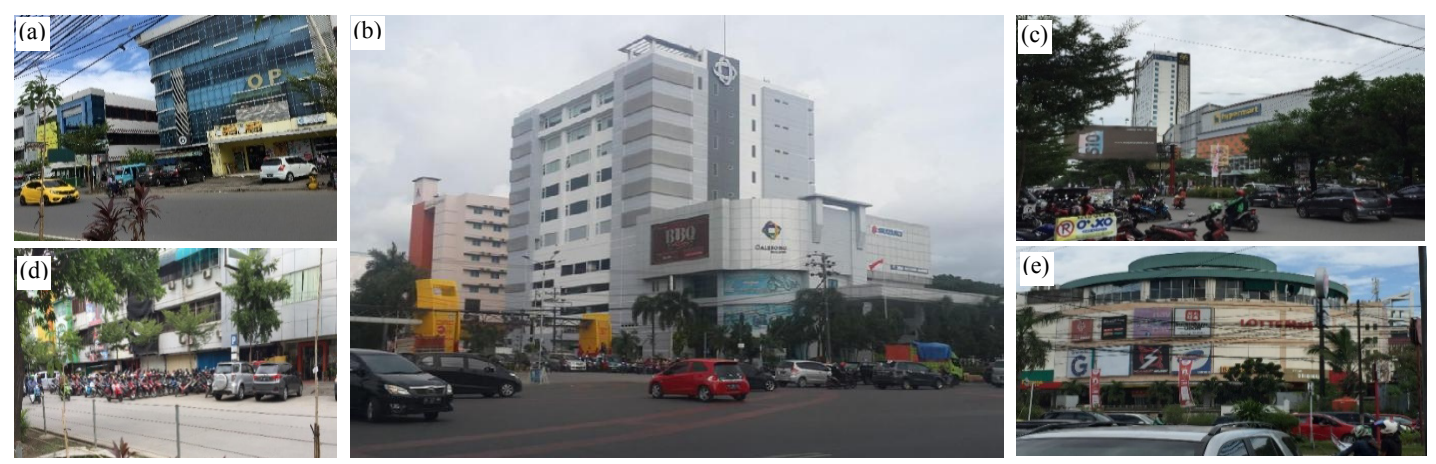

Fig. 7(a-e): Formal economic activities at Panakkukang Business Center, Makassar city; Primary Data
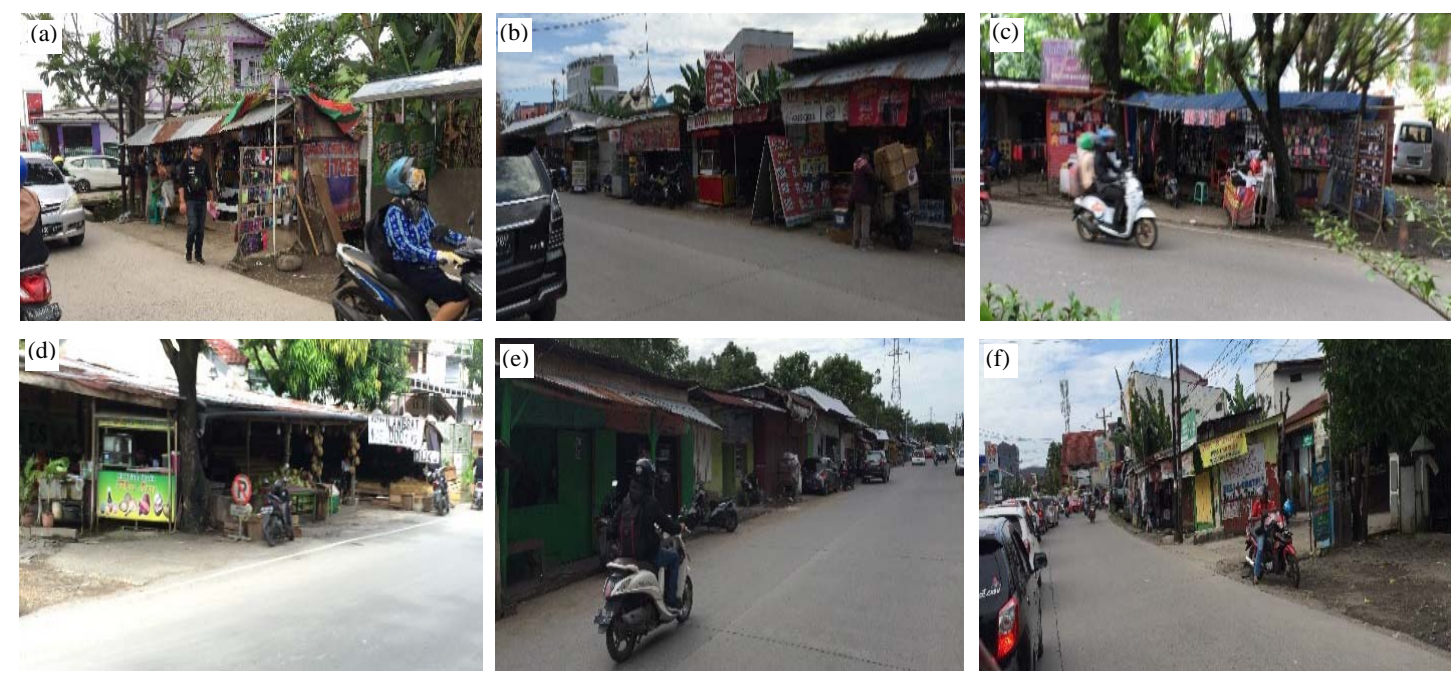

Fig. 8(a-f): Formal economy at Panakkukang Business Center, Makassar city; Primary Data

the analysis results also showed an $\mathrm{R}^{2}$ value of 0.052 which indicates that the variables $\mathrm{X} 1, \mathrm{X} 2$ and $\mathrm{X} 3$ contribute $5.20 \%$ to $\mathrm{Y}$, hence, $94.8 \%$ of informal economic activities were due to other factors. Therefore, this concludes that the existence of informal economic activities directly impacts on the spatial system of the subdistrict, due to increasing population, ease of access to various urban facilities and the development of commercial accomplishments. Furthermore, the strength of fiscal linkages between cities is closely related to distance, population and levels of development (Ye et al., 2019) (Fig. 9) (Table 2).

Economic and social empowerment of urban poor communities: Socio-economy empowerment in relation

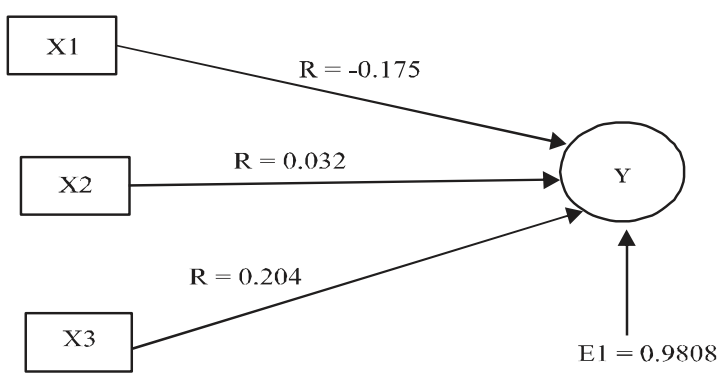

Fig. 9: Direct influence of the existence of in formal economic activities on the spatial system of the Panakkukang Sub-District in Makassar city; Analysis results 


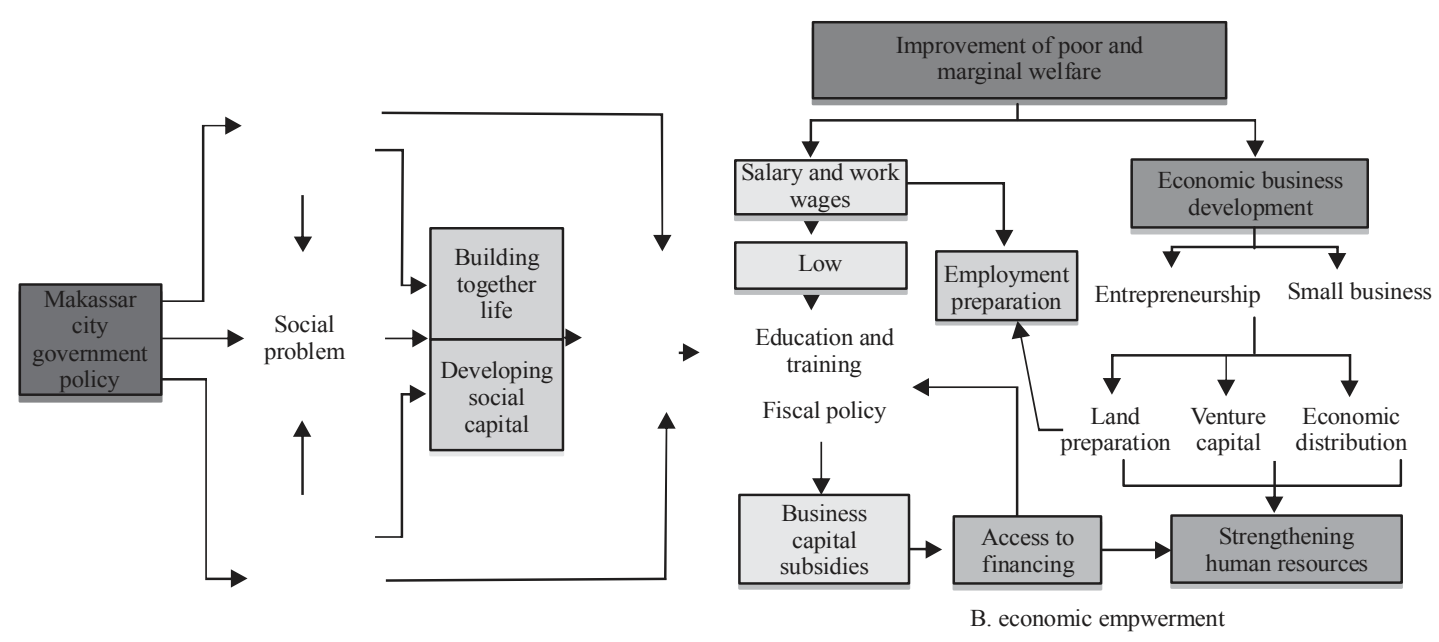

Fig. 10: The community socio-economy empowerment in Panakkukang Sub-District, Makassar city; Analysis results

to slums and informal economic activities management in the Panakkukang Sub-District area was carried out through several stages as seen in the following scheme (Table 2).

Figure 10 shows the processes and stages of socio-economic empowerment of the community which could be implemented to overcome the problem of slums and informal economic activities in the region. Some interpretations obtained include: the process is carried out in stage which includes development policies oriented towards solving social problems, through the provision of employment, utilizing community collective capital in order to create life, based on local wisdom and care, to create social justice and availability of settlements for the poor and marginal within the community. However, another important point to be considered while making policies includes target preventive measures against poverty by encouraging the poor in their economic, social and cultural lives, through the provision of training for labor market demands and further strengthening the industrial market for them (Zahra et al., 2018). Community fiscal empowerment, through interinstitutional collaboration, is capable of being conducted through strengthening the tenure of its production factors and its distribution and marketing, consolidation the capacity of the society to obtain decent and adequate wages as well as information, knowledge and skills, supported by the policies of the Makassar city government. Furthermore, developing economics must, therefore be concerned with the formulation of appropriate public policies, designed to affect major economic, institutional and social transformations of the entire society, in the shortest possible time (Ahmad and Abdullah, 2013).

Sustainability of slum settlement and urban in formal economic activities: The sustainability of slums and informal fiscal activities management, through the socio-economy empowerment of the people in Panakkukang Sub-District were carried out based on Government decisions, consolidation of the socioeconomic capacity of the community, optimizing societal capital to resolve conflicts, empowering public productivity and improving the quality of infrastructure, through the rejuvenation of residential environment. Hence, these can be seen in Fig. 11.

Interpretations obtained from Fig. 11 include decision making and formulation of slums management programs, implemented by involving the community, consolidating institutional capacity, through training, to foster entrepreneurship and further develop local fiscal potential, capital support through symbiotic mutualism cooperation and conflict resolution, development of productive economic enterprises in order to encourage community welfare and support for infrastructural development to facilitate mobility, access to market and resources of the city as well as environmental pollution control. However, the marketplace offers a unique entrepreneurial space which facilitates migrant's integration into urban society and also fosters interaction with local residents to form social networks (Chen and Liu, 2019). Furthermore, the principles oriented towards the sustainability of slums as well as management of informal economic activities, specific to the Panakkukang Sub-District, Makassar city is attributed to three main pillars, namely: shanty house management, through the application of the concept of residential environment rejuvenation, achieved by improving the quality of infrastructure, providing sanitation, waste management and distribution of clean water networks, sustainability of the informal economy, oriented towards increasing local economic productivity, creating economic independence, market protection and business capital assistance, through government policy, social balance, oriented towards solving communal conflicts, creating public cohesion, strengthening their institutional capacity, based on local 


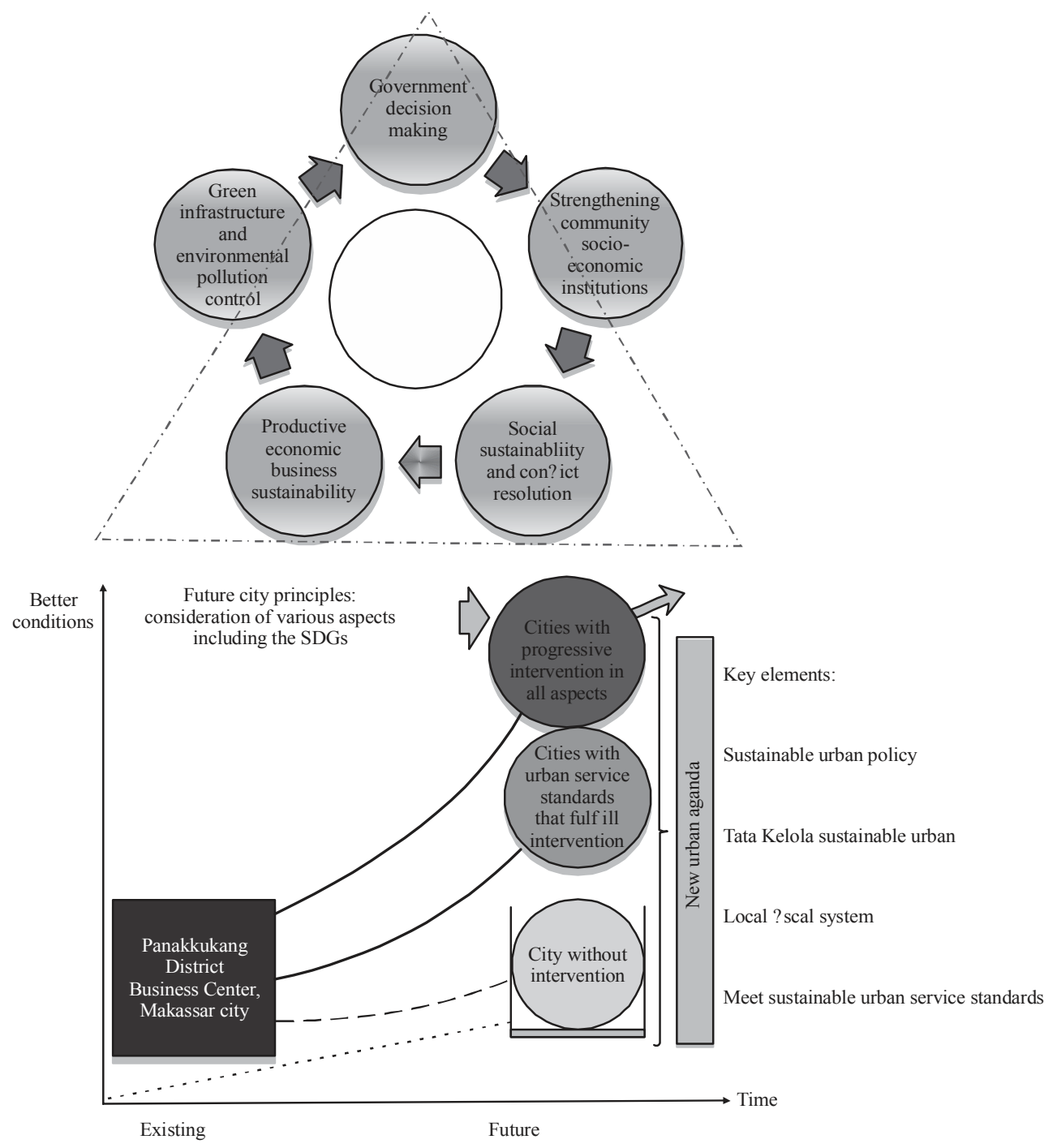

Fig. 11: Sustainability of slums management and improvement of urban informal economy; Analysis results

wisdom and also, the optimization of societal capital, supported by government policies. The effective implementation of these principles succeeds with the collaboration between the government, private sector and the community. Furthermore, the use of informal mechanisms to extend services had no effect on legal tenure status but it improved de facto and perceived tenure security. Understanding these 'negotiated institution's and how they emerge is crucial to their harnessing capability for the advantage of unauthorized communities which lack access to basic services (Hylton and Charles, 2018).

\section{CONCLUSION}

From the results of the discussion, the conclusions of this study are as follows: The partisanship of development policies oriented towards capitalists and neglectingthe poor communities causes the emergence of slums in protected areas of the Panakkukang Sub-District of Makassar city. However, their presence in the business center features the decline in environmental quality and standards of infrastructure services as well asthe increasein social problems. The inability of a community to access the city's economic resources initiates the growth of shanty houses, inhabited by poor and marginal groups. Furthermore, these regionsrequire infrastructure management, improvement of the quality of the surrounding and fulfillment of facilities and infrastructure to be integrated with urban systems. Hence, governmental alignments with the poor and marginal communities are implemented through the formulation of comprehensive and integrated programs as well as planning mechanisms which lead to the sustainability of physical, economic and socio-cultural development. 
Socio-economic empowerment is therefore carried out through developing policies oriented towards solving public problems, through the provision of employment, utilization of societal capital to create life, based on local wisdom and care, in order to create communal justice and availability of settlements for the poor and marginal. Furthermore, community fiscal empowerment, through inter-institutional collaboration is probable, through strengthening the tenure of community economic production factors, reinforcing the occupancy of distribution and marketing, fortifying the capacity of the community to obtain decent and adequate wages and consolidating to societal ability to harness information, knowledge and skills, supported by the policies of the Makassar city government

Slums and informal economic activities management in Panakkukang Sub-District, Makassar city is oriented to three main pillars which include: administration through the application of the concept of residential environment rejuvenation, achieved by improving the quality of infrastructure, providing sanitation, waste management and distribution of clean water networks, the sustainability of the unauthorized economy is oriented towards increasing local fiscal productivity, creating monetary independence, market protection and business capital assistance, through government policy, social viability, focused on solving public conflicts, creating communal cohesion, strengthening the capacity of civic institutions, based on local wisdom and also, optimizing shared capital, supported by government policies on marginalized and urban poor communities.

\section{ACKNOWLEDGEMENT}

The research team appreciate the reviewers for providing valuable and constructive input to this study.

\section{REFERENCES}

Acolin, A., M.C. Hoek-Smit and C.M. Eloy, 2019. High delinquency rates in Brazil's Minha Casa Minha Vida housing program: Possible causes and necessary reforms. J. Habitat Intl., 83: 99-110.

Ahmad, P., F. Yusof and F. Abdullah, 2013. Local economic growth and community sustainability. Procedia Soc. Behav. Sci., 101: 437-444.

Alberti, J., M. Roca, C. Brodhag and P. Fullana-I-Palmer, 2019. Allocation and system boundary in life cycle assessments of cities. J. Habitat Intl., 83: 41-54.

Balogh, A., P. Bajmocy and Z. Ilcsikne-Makra, 2018. Social and ethnic segregation amongst the smallest Hungarian villages. Geog. Pannonica, 22: 208-218.
Chen, Y. and C.Y. Liu, 2019. Self-employed migrants and their entrepreneurial space in megacities: A Beijing farmers market. Habitat Intl., 83: 125-134.

Denzin and Lincoln, 2009. Hand Book of Qualitative Research. Pustaka Pelajar Penerbit, Yogyakarta, Indonesia,

Ding, C., S.K. Lai and M.S. Wang, 2012. Global urbanization and Urban management. J. Urban Manage., 1: 1-2.

Farinmadea, A., O. Soyinkab and K.W.M. Siu, 2018. Assessing the effect of urban informal economic activity on the quality of the built environment for sustainable urban development in Lagos, Nigeria. Sustainable Cities Soc., 41: 13-21.

Fox, S., D. Ney and E. Verrucci, 2019. Liberalisation, urban governance and gridlock: Diagnosing Yangon's mobility crisis. Cities, 84: 83-95.

Friesen, J., H. Taubenbock, M. Wurm and P.F. Pelz, 2018. The similar size of slums. J. Habitat Intl., 73: 79-88.

Han, H. and S.K. Lai, 2012. National land use management in China: An analytic framework. J. Urban Manage., 1: 3-36.

He, Y., G. Zhou, C. Tang, S. Fan and X. Guo, 2019. The spatial organization pattern of urban-rural integration in urban agglomerations in China: An agglomerationdiffusion analysis of the population and firms. Habitat Intl., 87: 54-65.

Hylton, E. and K.J. Charles, 2018. Informal mechanisms to regularize informal settlements: Water services in Sao Paulo's favelas. J. Habitat Intl., 80: 41-48.

Kashkouli, A.B., A. Zarabi and M.N. Mousavi, 2018. The role of creative economy in the realization of a creative city: A case study of the city of Meybod in Yazd Province, Iran. Geographia Pol., 91: 335-351.

Lang, W., T. Chen, E.H. Chan, E.H. Yung and T.C. Lee, 2019. Understanding livable dense urban form for shaping the landscape of community facilities in Hong Kong using fine-scale measurements. Cities, 84: 34-45.

Maalsen, S., 2019. Smart housing: The political and market responses of the intersections between housing, new sharing economies and smart cities. Cities, 84: 1-7.

Menshikov, V. and O.I. Volkova, 2018. Economic growth and impact of institutions on quality of human capital: A case study. J. Secur. Sustainability Issues, 8: 248-256.

Olajide, O.A., M.E. Agunbiade and H.B. Bishi, 2018. The realities of Lagos urban development vision on livelihoods of the urban poor. J. Urban Manage., 7: 21-31.

Pedro, A.A. and A.P. Queiroz, 2019. Slum: Comparing municipal and census basemaps. J. Habitat Intl., 83: 30-40.

Saaty, T.L. and M. Sagir, 2015. Choosing the best city of the future. J. Urban Manage., 4: 3-23. 
Sharifi, A., 2019. Resilient urban forms: A macro-scale analysis. Cities, 85: 1-14.

Soyinka, O. and K.W.M. Siu, 2018. Urban informality, housing insecurity and social exclusion: Urban development. City Culture Soc., 15: 23-36.

Sulemana, I., E. Nketiah-Amponsah, E.A. Codjoe and J.A.N. Andoh, 2019. Urbanization and income inequality in Sub-Saharan Africa. Sustainable Cities Soc., 48: 1-4.

Surya, B. and H. Saleh, 2018. Transformation of metropolitan suburban area (a study on new town development in Moncongloe-Pattalassang metropolitan maminasata). IOP. Conf. Ser. Earth. Environ. Sci., Vol. 202, 10.1088/1755$1315 / 202 / 1 / 012027$

Surya, B., 2015b. Spatial articulation and Co-existence of mode of production in the dynamics of development at the urban fringe of Makassar City. J. Eng. Appl. Sci., 10: 214-222.

Surya, B., 2015a. The dynamics of spatial structure and spatial pattern changes at the fringe area of Makassar city. Indonesian J. Geography, 47: 11-19.

Surya, B., H. Saleh and H. Remmang, 2018. Economic gentrification and socio-cultural transformation metropolitan suburban of Mamminasata. J. Eng. Appl. Sci., 13: 6072-6084.

Surya, B., M. Ruslan and H. Abubakar, 2018. Inequility of space reproduction control and Urban slum area Management Sustainability (case study: Slum area of Buloa urban village in Makassar City). J. Eng. Appl. Sci., 13: 6033-6042.
Timberlake, M., Y.D. Wei, X. Ma and J. Hao, 2014. Global cities with Chinese characteristics. Cities, 41: $162-170$.

Wang, L., 2014. Forging growth by governing the market in reform-era Urban China. Cities, 41: 187-193.

Yang, Y. and N. Hu, 2019. The spatial and temporal evolution of coordinated ecological and socioeconomic development in the provinces along the Silk Road Economic Belt in China. Sustainable Cities Soc., Vol. 47,

Ye, C., J. Zhu, S. Li, S. Yang and M. Chen, 2019. Assessment and analysis of regional economic collaborative development within an Urban agglomeration: Yangtze River Delta as a case study. J. Habitat Intl., 83: 20-29.

Yi, H., U.P. Kreuter, D. Han and B. Guneralp, 2019. Social segregation of ecosystem services delivery in the San Antonio region, Texas, through 2050. Sci. Total Environ., 667: 234-247.

Zahra, K., A. Ashraf, T. Zafar and B.M. Yaseen, 2018. Marginality and social exclusion in Punjab, Pakistan: A threat to urban sustainability. Sustainable Cities Soc., 37: 203-212.

Zhang, S., 2014. Land-centered urban politics in transitional China-can they be explained by Growth Machine Theory?. Cities, 41: 179-186. 